\title{
Gene Encoding Nitrilase from Soil Sample of Lombok Gold Mine Industry using Metagenomics Approach
}

\section{Rini Riffani, Nunik Sulistinah, and Bambang Sunarko}

Division of Microbiology, Research Center for Biology, Indonesian Institutes of Science (LIPI), Jl. Raya Jakarta Bogor Km 46, Cibinong, Indonesia

\section{Abstract}

This paper describes a efficient screening gene nitrilase from contaminated soil from Lombok gold mine industry. DNA was extracted directly from soil using the soil DNA isolation kit based on enzymatic, chemical and mechanical lysis. The existence of nitrilase gene in soil sample can be identified by nitrilase gene amplification using $\mathrm{H}_{1} \mathrm{~F}-\mathrm{H}_{1} \mathrm{R}$ primer. BLASTN analysis result revealed that the nitrilase gene fragment which was amplified by $\mathrm{H}_{1} \mathrm{~F}-\mathrm{H}_{1} \mathrm{R}$ primer has a high homology with Rhodococcus rhodochrous strain tg1-A6 nitrilase gene. These amplification and DNA fragment sequencing results indicated that nitrilase gene existence on soil sample can be identified by metagenomic approach

Corresponding Author:

Rini Riffani

rini.riffani@gmail.com

Received: 11 February 2017

Accepted: 08 March 2017

Published: 26 March 2017

Publishing services provided by Knowledge $\mathrm{B}$

(c) Rini Riffani et al. This article is distributed under the terms of the Creative Commons

Attribution License, which permits unrestricted use and redistribution provided that the original author and source are credited.

Selection and Peer-review under the responsibility of the ICBS Conference Committee.

G OPEN ACCESS
Keywords: Metagenomics; nitrilase gene; Rhodococcus rhodochrous; soil.

\section{Introduction}

The biosphere is dominated by microorganisms however mostly they have not been studied. Traditional methods for culturing microorganisms limit analysis to those that grow under laboratory condition [1]. Demand for novel biocatalysts is continuously increased and thereby prompting the development of novel experimental approaches to find and identify novel biocatalyst-encoding genes. Recently, there has been an increase in the number of studies using a metagenomics approach to investigate the catalytic potential of uncultured microorganisms [2].

In the search for novel biocatalysts, there are various metagenomic strategies used for discovery of enzymes for a broad spectrum of biotechnological applications. Enzymes are key to all biosynthetic pathways in the production of natural metabolites in microbial system. Direct cloning has led to important discoveries of genes responsible for novel biological functions. New genetic information on various industrial enzyme such as metagenomic approaches [3].

Nitrilases are enzymes that hydrolyse non peptide carbon-nitrogen bonds. They are important industrial enzymes used to convert nitriles $(\mathrm{R}-\mathrm{C} \equiv \mathrm{N})$ such as cyanide, directly into corresponding acids and ammonia. Nitrilases are quite rare in bacterial genomes 


\begin{tabular}{l|l|c|c|c|}
\hline Primers & Sequence & Tm ( $\left.{ }^{\circ} \mathrm{C}\right)$ & $\%$ GC & $\Sigma$ base (pb) \\
\hline $\mathrm{H}_{1} \mathrm{~F}$ & $5^{\prime}$-CGTACCACATCTGGGACAGC-3' & 74 & 60.9 & 20 \\
\hline $\mathrm{H}_{1} \mathrm{R}$ & 5'-TCCGTCTCGGAATGTGTGGA-3' $^{\prime}$ & 66 & 52 & 20 \\
\hline
\end{tabular}

TABLE 1: Nucleotide primers used for PCR detection and amplification of nitrilase encoding genes.

and less than 20 were reported before the application of metagenomics for their detection in environmental DNA. Two studies targeting environmental genomes report the detection of more than 337 novel nitrilases [4]. This has dramatically increased of interest on studying nitrilases and the newly discovered diversity can be applied for the enantioselective production hydroxyl carboxylic acid derivates [5, 6]. The variety of newly discovered nitrilases represents a broad diversity of nitrilase sequence space.

Nitrilases have been promoted to be a valuable alternative to chemical hydrolysis in an organic chemical processes because of their mild reaction conditions and reduced output of environmental pollution [7]. However, environmental problems caused by cyanide are due to the production of large amounts of cyanide-containing wastes by human industrial activities, such as production of organic nitriles, nylon and acrylic plastics, paints, drugs and the use of cyanide in gold mining and the metal industries [8].

Gold mining in developing countries can be organized and regulated with mechanisms in place to protect workers and the environment. But mining can also informal and small-scale with minimal regulatory control of activities. This second form of mining is described as artisanal or small-scale gold mining (ASGM). Recently, the increased gold price can be seen to the extent of operations to the island of Lombok and Sumbawa. Physicohemical extreme environment such as highly polluted environments contain a low microbial community size. Microbe that is capable of living in this hostile environment has evolved special mechanisms for survival. Due to the low community size and biomass of these habitats are not as readily available as other environments by metagenomic approaches [9]. For this purpose, an efficient screening gene nitrilase from contaminated soil from gold mining by metagenomes approach have been introduced.

\section{Materials and Method}

\subsection{Research Location}

The research was conducted through a field survey of the Sekotong (South West Lombok), Keruak and Sekarbela during Mei 2011. Cyanidation and mercury tailings were sampled directly from tailings dams. On Lombok, hard-rock mining occurs throughout the Sekotong region, with ore transported as far as capital city Mataram for processing (Sekarbela). But in Sumbawa, amalgamation and cyanidation facilities have been constructed close to the point for ore extraction. The extent of mining activity is increasing in both Sekotong and Sumbawa. These samples had been chosen due to suspected 
elevated metal content, and a number of cyanide and nitrile degrading bacteria had previously been isolated from these soil.

\subsection{Soil preparations}

\subsubsection{DNA extraction}

Soil DNA extraction was performed using the soil DNA isolation kit (Mobio laboratories, USA) based on enzymatic, chemical and mechanical lysis.

\subsubsection{DNA quantitation}

For quantitating DNA, quantitation of double stranded DNA was calculated from the optical density absorbance value measured by a spectrophotometer (ABI) using wavelengths of $260 \mathrm{~nm}$ and $280 \mathrm{~nm}$. PCR condition. Reaction mixture for PCR contained: 25 $\mu \mathrm{L}$ go tag buffer $2.5 \mu \mathrm{L}$ complete, $0.5 \mu \mathrm{L}$ dNTPs, $1.0 \mu \mathrm{L}$ primer $1,1.0 \mu \mathrm{L}$ primer 2, 0.5 $\mu \mathrm{L}$ (1 unit) DNA Taq polymerase, $1 \mu \mathrm{L}$ DNA, $1.5 \mu \mathrm{L} \mathrm{MgCl} 225 \mathrm{mM}, 18 \mu \mathrm{L} \mathrm{ddH_{2 } O}$ in final volume $50 \mu \mathrm{l}$. DNA amplification was performed with thermocycler Takara (Japan) by using the followed program: 10 min hotstart at $94^{\circ} \mathrm{C}$ followed by 35 cycles consisting of denaturation ( 2 min at $94^{\circ} \mathrm{C}$ ), annealing $\left(60 \mathrm{~s}\right.$ at $52^{\circ} \mathrm{C}$ ), extension $\left(90 \mathrm{~s}\right.$ at $72^{\circ} \mathrm{C}$ ) and a final extension step at $72^{\circ} \mathrm{C}$ for $5 \mathrm{~min}$. PCR product was analysed in $1 \%$ agarose gel electrophoresis run with TAE buffer ( $40 \mathrm{mM}$ Tris-acetate $\mathrm{pH}$ 8,1 mM EDTA) and stained with ethidium bromide. The primer used for nitrilase encoding gen amplification are listed in Table 1, Genomic DNA of Rhodococcus pyridinovorons TPIK was used as positive control.

\subsubsection{Gel electrophoresis}

After PCR amplification, the amplified PCR products were checked for expected size on $1.5 \%$ (w/v) agarose gel (LE analytical grade Promega, Madison, USA). Agarose gel was loaded with $10 \mu \mathrm{L}$ of each PCR amplified product and run in $1 \times$ TAE. A ready-to-use 1 Kb plus DNA Ladder-molecular weight standard (Novagen, USA) and negative control were run together with the PCR amplified products. The PCR product was separated by electrophoresis system at a constant voltage of $80 \mathrm{~V}$ for 50 min. Then, the gel was stained with ethidium bromide staining $\left(0.5 \mu \mathrm{g} \cdot \mathrm{mL}^{-1}\right)$ for $30 \mathrm{~min}$ and followed by washing with distilled water for about 3 min. Finally, the gel was visualized under UV transilluminator, and photos were taken using gel documentation system.

\subsubsection{Gel extraction (Qiagen)}

DNA fragment was excised from the agarose gel with a sharp scalpel and weigh the gel slice in a colorless tube. The gel was suspended in buffer QG (three volume buffer QG to one volume gel) and incubated at $50^{\circ} \mathrm{C}$ for $10 \mathrm{~min}$. Every $2 \mathrm{~min}$ to $3 \mathrm{~min}$ solution was mix well to help dissolve gel. After the gel slice has dissolved completely add one 
gel volume of isopropanol and mixed gently upside down. The mixture was applied to the quick column then centrifuged for 1 min. The flow-through was discarded and placed column back in the same collection. $750 \mu \mathrm{L}$ of Buffer PE was added to quick column and centrifugated for $1 \mathrm{~min}$. The flow-through was discarded and centrifuged the column for additional then placed column into a clean $1.5 \mathrm{~mL}$ microcentrifuge tube. DNA was elute with Buffer EB or TE buffer and stored a $-20^{\circ} \mathrm{C}$.

\subsubsection{Nucleotide sequencing and sequence analysis}

Nucleotide sequences were determined via 1st BASE (Singapore) and analysed using blastn or blastx software [10]. from the GeneBank (NCB1) database.

\section{Results and Discussions}

\subsection{DNA purity}

The purity of the DNA extracts is important for gene amplification by PCR and further analysis such as DGGE fingerprinting or cloning of amplicons. To examine the purity of DNA extracts, the UV absorptions at $260 \mathrm{~nm}$ and $280 \mathrm{~nm}$ were measured and the ratio of $260: 280$ were calculated. The quality of the extracted DNA was evaluated by the $A_{260}: A_{280}$ ratio and values high than 1.8 indicate a good DNA extract without protein or humic acid contamination [11]. The DNA samples have OD $A_{260}: A_{280}$ ratio around 0.613 to 1.3. DNA extracts of the soil sample showed absorbance ratio below 1.8 , which reflects the co-xtraction of contaminant. Soil is particularly complex matrix containing many substances, such as humic acids, which can be co-extracted during DNA isolation. Removal of humic acids is essential before the DNA can be processed further. Because of this, a range of DNA purification techniques has been developing. The resulting DNA extracts were analysed by agarose gel elegctrophoresis (see Figure 1). Although DNA extract of the sample showed the below the detection limit, but showed sharp band in gel electrophoresis.

Soil is a particularly complex matrix containing many substances, such as humic acids, which can be co-extracted during DNA isolation. Removal of humic acids is essential before the DNA can be processed further. Because of this, a range of DNA purification techniques has been developed. Sephadex G-200 spin columns have proven to be one of the best to remove contaminants from soil DNA. Recently, a pulse field electrophoresis procedure using a two-phase agarose gel, with one phase containing polyvinylpyrrolidone (PVPP), was developed for removal of humics [12].

Critical steps in direct soil DNA extraction methods are lysis of microbial cells and eliminating humic acids, protein, and other inhibitors. For cell lysis to be effective, mechanical treatment should be followed rather than chemical ones. Various physical and chemical treatments have been evaluated for cell rupture, which include shaking the sample in lysis buffers, detergents or glass beads, inclusion of lysozyme [13].

The ultra clean soil kit DNA isolation kit remains the most highly cited purification method for soil in use today. Inhibitors like Humic acid, pulvic acids, polysaccharides 


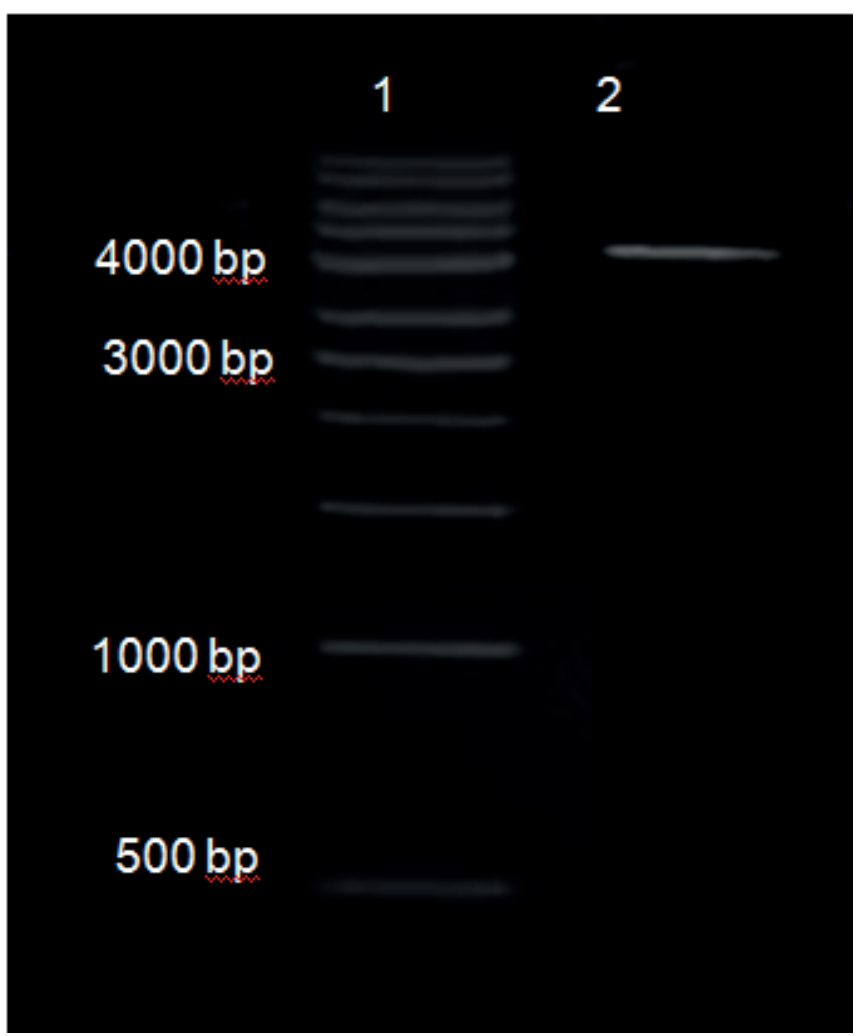

Figure 1: Electrophoresis of DNA extracted from soil samples, $6 \mu \mathrm{L}$ of eluted DNA was loaded on $1 \%$ agarose gel, and electrophoresis for 55 min Lane 1 = $1 \mathrm{~Kb}$ DNA ladder Marker; Lane 2, DNA extract.

and polyphenols are removed using IRT (Inhibitor Removal Technology) for the highest success rates in PCR of any commercial method. The ultraclean DNA isolation is fully compatible with bead beating technology if harder beating for lysis of tough organism is desired and provided the highest quality DNA based on successful amplification functional genes of nitrilase. We generated the expected 900 bp to 1100 bp fragment with soil extract from mining gold in Sekotong, Mataram.

\section{2. $P C R$ detection of nitrilase genes}

Following PCR using DNA extract from soil as the template, the amplification product was detected using agarose gel electrophoresis. As a shown in Figure 2 a specific DNA fragment (about 900 bp), which matched the correct size of the nitrilase gen was successfully amplified. Nevertheless, only smears of non-specific fragment were obtained indicating that may the primer were cross reacted with other DNA sequence.

The gel was extracted by QIAquick gel extraction kit for remove the non-specific fragment, the removed slice of gel should contain the desired DNA inside. Nitrilase gene fragment sequencing results of the soil samples were obtained base sequence of 957 bp. Those sequenced have been compared with another gene sequence of domain bacteria using the BLASTN program at NCBI webside. Furthermore analysis indicated that sequence are closely related to Rhodococcus rhodochrous strain tgl-A6 nitrilase gene with $99 \%$ homology. 


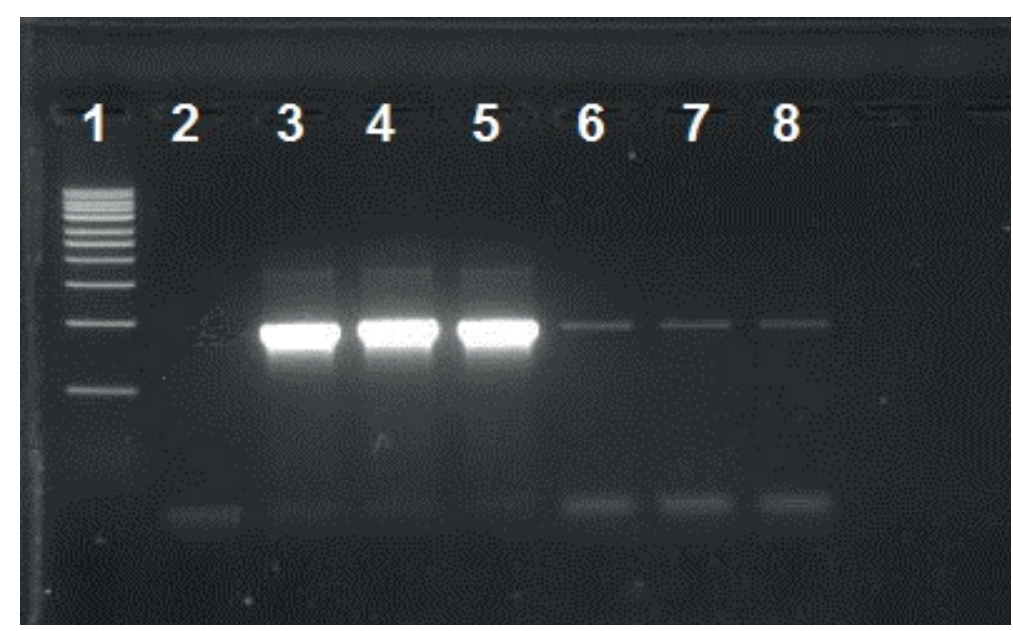

Figure 2: PCR amplification of the nitrilase-encoding gene amplified from soil contamined by cyanide. 6ख of eluted DNA was loaded on $1 \%$ agarose gel, and electrophoresis for $55 \mathrm{~min}$. Lane $1=1 \mathrm{~Kb}$ DNA ladder marker, lane 2: control negative, without DNA template, lane 3 to 5: Genomic DNA template of Rhodococcus pyridinovorans TPIK was used as positive control. Lane 6 to 8 DNA amplified.

\section{Conclusion}

The existence of nitrilase gene in soil sample from Lombok gold mine industry can be identified by direct DNA extraction and nitrilase gene amplification using $\mathrm{H}_{1} \mathrm{~F}-\mathrm{H}_{1} \mathrm{R}$ primer. BLASTN analysis result revealed that the nitrilase gene fragment which was amplified by $\mathrm{H}_{1} \mathrm{~F}-\mathrm{H}_{1} \mathrm{R}$ primer has a high homology with Rhodococcus rhodochrous strain tg1-A6 nitrilase gene.

\section{Acknowledgements}

This work was supported by funding from Incentive Program Research And Application in LIPI, 2011-2012.

\section{References}

[1] M. R. Rondon, P. R. August, A. D. Bettermann et al., "Cloning the soil metagenome: A strategy for accessing the genetic and functional diversity of uncultured microorganisms," Applied and Environmental Microbiology, vol. 66, no. 6, pp. 2541$2547,2000$.

[2] C. Elend, C. Schmeisser, C. Leggewie et al., "Isolation and biochemical characterization of two novel metagenome-derived esterases," Applied and Environmental Microbiology, vol. 72, no. 5, pp. 3637-3645, 2006.

[3] Wong. DWS, "Applications of metagenomics for industrial bioproducts," in Metagenomics:, theory, methods and applications, D. Marco, Ed., pp. 141-158, Caister Academic Press, Norfolk, UK, 2010.

[4] G. DeSantis, Z. Zhu, W. A. Greenberg et al., "An enzyme library approach to biocatalysis: Development of nitrilases for enantioselective production of 
carboxylic acid derivatives," Journal of the American Chemical Society, vol. 124, no. 31, pp. 9024-9025, 2002.

[5] M. Podar, J. R. Eads, and T. H. Richardson, "Evolution of a microbial nitrilase gene family: A comparative and environmental genomics study," BMC Evolutionary Biology, vol. 5, 2005.

[6] D. E. Robertson, J. A. Chaplin, G. D. Santis, M. Podar, M. Madden, and E. Chi, "Evolution of microbial nitrilase family: a comparative and environmental genomics study," BMC Evolutionary Biology, vol. 5, 2005.

[7] S.-J. Yeom, H.-J. Kim, J.-K. Lee, D.-E. Kim, and D.-K. Oh, "An amino acid at position 142 in nitrilase from Rhodococcus rhodochrous ATCC 33278 determines the substrate specificity for aliphatic and aromatic nitriles," Biochemical Journal, vol. 415, no. 3, pp. 401-407, 2008.

[8] L. J. Basile, R. C. Willson, B. T. Sewell, and M. J. Benedik, "Genome mining of cyanide-degrading nitrilases from filamentous fungi," Applied Microbiology and Biotechnology, vol. 80, no. 3, pp. 427-435, 2008.

[9] C. Simon and R. Daniel, "Achievements and new knowledge unraveled by metagenomic approaches," Applied Microbiology and Biotechnology, vol. 85, no. 2, Pp. 265-276, 2009.

[10] S. F. Altschul, T. L. Madden, A. A. Schäffer et al., "Gapped BLAST and PSI-BLAST: A new generation of protein database search programs," Nucleic Acids Research, vol. 25, no. 17, pp. 3389-3402, 1997.

[11] S. Knauth, H. Schmidt, and R. Tippkötter, "Comparison of commercial kits for the extraction of DNA from paddy soils," Letters in Applied Microbiology, vol. 56, no. 3, Pp. 222-228, 2013.

[12] A. Quaiser, T. Ochsenreiter, H.-P. Klenk et al., "First insight into the genome of an uncultivated crenarchaeote from soil," Environmental Microbiology, vol. 4, no. 10, pp. 603-611, 2002.

[13] F. Fatima, I. Chaudhary, J. Ali, S. Rastogi, and N. Pathak, "Microbial DNA extraction from soil by different methods and its PCR amplification," Biochemical and Cellular Archives, vol. 11, no. 1, pp. 85-90, 2011. 